\begin{tabular}{|c|c|c|}
\hline & $\begin{array}{c}\text { International Journal of Current Research in } \\
\text { Biosciences and Plant Biology } \\
\text { BXCELLENT } \\
\text { PUBLISHERS }\end{array}$ \\
Volume $4 \bullet$ Number 5 (May-2017) $・$ ISSN: 2349-8080 (Online) \\
Journal homepage: www.ijcrbp.com
\end{tabular}

\title{
Ethnobotanical Investigation and Collection of the Local Maize (Zea mays L.) Varieties Produced in Benin
}

\author{
Z. Bonou-gbo*, G. Djedatin, A. Dansi, I. Dossou-Aminon, C. T. Odjo, W. Djengue and K. Kombate
}

Laboratory of Biotechnology, Genetic Resources and Plant and Animal Breeding (BIORAVE), Faculty of Sciences and Technology of Dassa, National University of Sciences, Technologies, Engineering and Mathematics, PO Box P143, Dassa, Benin

*Corresponding author.

\begin{tabular}{|c|c|}
\hline Abstract & Article Info \\
\hline \multirow{7}{*}{$\begin{array}{l}\text { Although maize is an economic crop among agroecological zones in Benin, there is a } \\
\text { limited information on its varietal diversity, production constraints and ethnobotanical } \\
\text { knowledge. To fill this gap, ethnobotanical survey was conducted among } 51 \text { communities } \\
\text { from } 22 \text { ethnic groups randomly selected from } 11 \text { departments in Benin using } \\
\text { participatory rural appraisal. A total of } 161 \text { accession names of maize were recorded and } \\
\text { collected from the study area. Results of the study showed a strong correlation between } \\
\text { the age of the producers and the number of varieties produced. Similarly, there was a } \\
\text { relationship between total maize yield produced and size of the farm cultivated. In the } \\
\text { North, maize varieties are classified based on seed color or maturity period, while in the } \\
\text { South plant morphology and origin are mostly used. Across ethnic groups, variety } \\
\text { preference criteria depended on specific production constraints and its socio-cultural } \\
\text { importance. Based on the perceived agronomic traits of the varieties reported by farmers, } \\
\text { collected samples were clustered into four groups of complementary characteristics that } \\
\text { are of high importance for maize breeding in Benin. }\end{array}$} & $\begin{array}{l}\text { Accepted: } 27 \text { March } 2017 \\
\text { Available Online: 06 May } 2017\end{array}$ \\
\hline & Keywords \\
\hline & Diversity \\
\hline & Maize varieties \\
\hline & Production constraint \\
\hline & Yield \\
\hline & \\
\hline
\end{tabular}

\section{Introduction}

Maize (Zea mays L.) is an important crop in the world. Globally, an estimated 1.038 billion tons was produced in 2014 (FAO, 2016). Compared with wheat and rice, it is estimated to provide about $30 \%$ of the total nutritional calories of almost 94 countries in the developing world (Shiferaw et al., 2011). It is also an important source of animal feed and serves as raw material for several agro based industries (Boone et al., 2008; Shiferaw et al., 2011; Badu-Apraku et al., 2014). Since its introduction to West Africa, it has progressed to become an economic crop with several varieties developed for different agro-ecological zones (Badu-Apraku et al., 2014). In Benin, it is cultivated in all the agroecological zones and plays an important role in the country's economy. Production is characterized by small holder farmers with farm size ranging between 0.5 and 2 ha. Increase in productivity has been attributed to increased production area and not mainly due to the use of improved inputs. The national production is estimated at about 1.1 million tons cultivated on an area of 938,845.7 ha (Countrystat, 2014). The low yield can be attributed to several factors such as poor edaphic conditions, bad agronomic practices and most importantly the use of poor quality seed which is due to 
lack of uniformity planting material. Seeds play a pivotal role in agricultural productivity and the breeding for good quality seed for use by farmers depends on basically on understanding, identification, collection and utilization of diverse germplasm in breeding programs. Within countries, several maize varieties are in circulation with different names produced by farmers for several reasons apart from yield (Manda et al., 2016).In Cote d'Ivoire for instance some varieties such as the purple maize cultivated at Katiola and surrounding localities (Kouakou et al., 2010) are produced due to its socio-cultural importance. Due to the lack of a wellestablished national maize germplasm collection centers and standardized names for these varieties, farmers serves as both producers and biodiversity conservationist holding on to diverse maize varieties. They also serve as a repository of knowledge in determining and differentiating between maize varieties in their possession. In order to benefit from their knowledge resource, this study was conducted to document some maize accessions in Benin, the different accession names, origin of accession names, characteristics of maize farmers, production practices and constraints encountered among various ethnic groups in all agro-ecological zone of Benin where maize is produced. Specifically, the study sought to:

- Document the status of the existing local maize varietal diversity and the agronomic characteristics of the varieties.

- Document some production practices associated with maize production in the study areas.

- Assess some biotic and abiotic constraints associated with maize production in the study areas.

- Prioritize farmers' varietal preference criteria for breeding purposes.

\section{Materials and methods}

\section{Study area and site selection}

The study was conducted among 51 ethnic groups (Table 1) located in eight agro-ecological zones (Fig. 1) and 11 administrative departments of the country. Of the 11 administrative departments surveyed, 4 (Atacora, Donga, Alibori and Borgou) were located in the North, 1 (Collines) in the Centre and 6 (Zou, Oueme, Plateau, Mono, Couffo and Atlantique) in the South. The north has a single rainfall season with annual rainfall between 700 and $900 \mathrm{~mm}$ with an average temperature of between $28^{\circ} \mathrm{C}$ and $50^{\circ} \mathrm{C}$ (Hell et al., 2000; Adomou, 2005; Akoègninou et al., 2006; Loko et al., 2013).

AEZ II and AEZ III, found in the cotton zone of Northern Benin and the food-producing zone of Southern Borgou respectively falls under the Sudan climate condition with a mean rainfall of 900 to 1300 $\mathrm{mm}$ and a temperature range of between 28 to $40^{\circ} \mathrm{C}$ annually (Hell et al., 2000). West Atacora zone located in AEZ IV falls in the Sudan transition zone and experiences a mean annual rainfall of between 800 and $1400 \mathrm{~mm}$. However, AEZ V (Central Benin), AEZ VI (Zone of Bar Ground), AEZ VII (Zone of Depression) and AEZ VIII (Zone of Fisheries) are characterized with two rainy seasons with annual rainfall of 1100 and 1400 $\mathrm{mm}$ and mean annual temperatures of between 25 and $35^{\circ} \mathrm{C}$. The collection of maize varieties included two to five municipalities per department. The municipalities were not only chosen proportionately to the maize production in each department during the cycle of production but also as a function of ethnic groups' repartition in the department. When prospective zone was not reached for target villages, cultivated territory of each municipality has been considered. Therefore, fifty one villages were investigated in proportion of one to three villages per municipality (Table 1).

Table 1. List of villages surveyed their departments, municipalities and ethnic groups.

\begin{tabular}{lllll}
\hline $\mathbf{N}^{\circ}$ & Villages & Municipalities & Departments & Ethnic groups \\
\hline 1 & Adjantè & Bantè & COLLINES & Ifè \\
2 & Aïzè & Ouinhi & ZOU & Fon \\
3 & Alafiarou & Tchaourou & BORGOU & Bariba \\
4 & Atokolibé & Bantè & COLLINES & Ifè \\
5 & Awokpa & Zè & ATLANTIQUE & Aïzo \\
6 & Bassila-Allan & Bassilla & DONGA & Annii \\
7 & Béléfoungou & Djougou & DONGA & Yom \\
8 & Bétérou & Tchaourou & BORGOU & Bariba \\
\hline
\end{tabular}




\begin{tabular}{|c|c|c|c|c|}
\hline $\mathbf{N}^{\circ}$ & Villages & Municipalities & Departments & Ethnic groups \\
\hline 9 & Cotiakou & Tanguiéta & ATACORA & Wama \\
\hline 10 & Coussin-lélé & Covè & $\mathrm{ZOU}$ & Mahi \\
\hline 11 & Dendougou & Djougou & DONGA & Yom \\
\hline 12 & Dévé & Dogbo & COUFFO & Adja \\
\hline 13 & Dogbo-kounacho & Adja-ouèrè & PLATEAU & Holli \\
\hline 14 & Dogo & Kétou & PLATEAU & Mahi \\
\hline 15 & Domè & Zogbodomè & $\mathrm{ZOU}$ & Fon \\
\hline 16 & Dovi-Zounou & Zangnanado & $\mathrm{ZOU}$ & Mahi \\
\hline 17 & Fô-bouré & Sinendé & BORGOU & Bariba \\
\hline 18 & Fô-Tancé & Kouandé & ATACORA & Bariba \\
\hline 19 & Founougo & Banikoara & ALIBORI & Bariba \\
\hline 20 & Gativé & Comé & MONO & Watchi \\
\hline 21 & Gobè & Savè & COLLINES & Idaatcha \\
\hline 22 & Gouti & Adjohoun & OUEME & Wémé \\
\hline 23 & Guézo-houé & Kpomassè & ATLANTIQUE & Sahouè \\
\hline 24 & Handin-sota & Dangbo & OUEME & Wémé \\
\hline 25 & Hokpamè & Athiémé & MONO & Adja \\
\hline 26 & Houéda & Adjohoun & OUEME & Wémé \\
\hline 27 & Houinga-Houégbé & Houéyogbé & MONO & Sahouè \\
\hline 28 & Kodowari & Bassilla & DONGA & Annii \\
\hline 29 & Koni & Nikki & BORGOU & Bariba \\
\hline 30 & Kpassabéga & Copargo & DONGA & Yom/Tanika \\
\hline 31 & Lagbavé & Aplahoué & COUFFO & Adja \\
\hline 32 & Lougou & Ségbana & ALIBORI & Boo \\
\hline 33 & Madécali & Malanville & ALIBORI & Dendi \\
\hline 34 & Madjavi & Djidja & $\mathrm{ZOU}$ & Fon \\
\hline 35 & Mitro & Dangbo & OUEME & Wémé \\
\hline 36 & Monkpa & Savalou & COLLINES & Mahi \\
\hline 37 & N'dahonta & Tanguiéta & ATACORA & Natimba \\
\hline 38 & Obi-cro & Savalou & COLLINES & Mahi \\
\hline 39 & Pélima & Kouandé & ATACORA & Bariba \\
\hline 40 & Piami & Ségbana & ALIBORI & Boo \\
\hline 41 & Sam & Kandi & ALIBORI & Bariba \\
\hline 42 & Sanrin-Kpinlè & Sakété & PLATEAU & Wémé \\
\hline 43 & Sèkèrè & Sinendé & BORGOU & Bariba \\
\hline 44 & Sèmèrè & Ouaké & DONGA & Foodo \\
\hline 45 & Sérékali & Nikki & BORGOU & Bariba \\
\hline 46 & Sinawongourou & Kandi & ALIBORI & Bariba \\
\hline 47 & Sowé & Glazoué & COLLINES & Mahi \\
\hline 48 & Tandji & Lalo & COUFFO & Adja \\
\hline 49 & Tapoga & Cobly & ATACORA & Gnidé/gountéma \\
\hline 50 & Toffo-centre & Toffo & ATLANTIQUE & Aïzo \\
\hline 51 & Toubougnini & Matéri & ATACORA & Berba \\
\hline
\end{tabular}




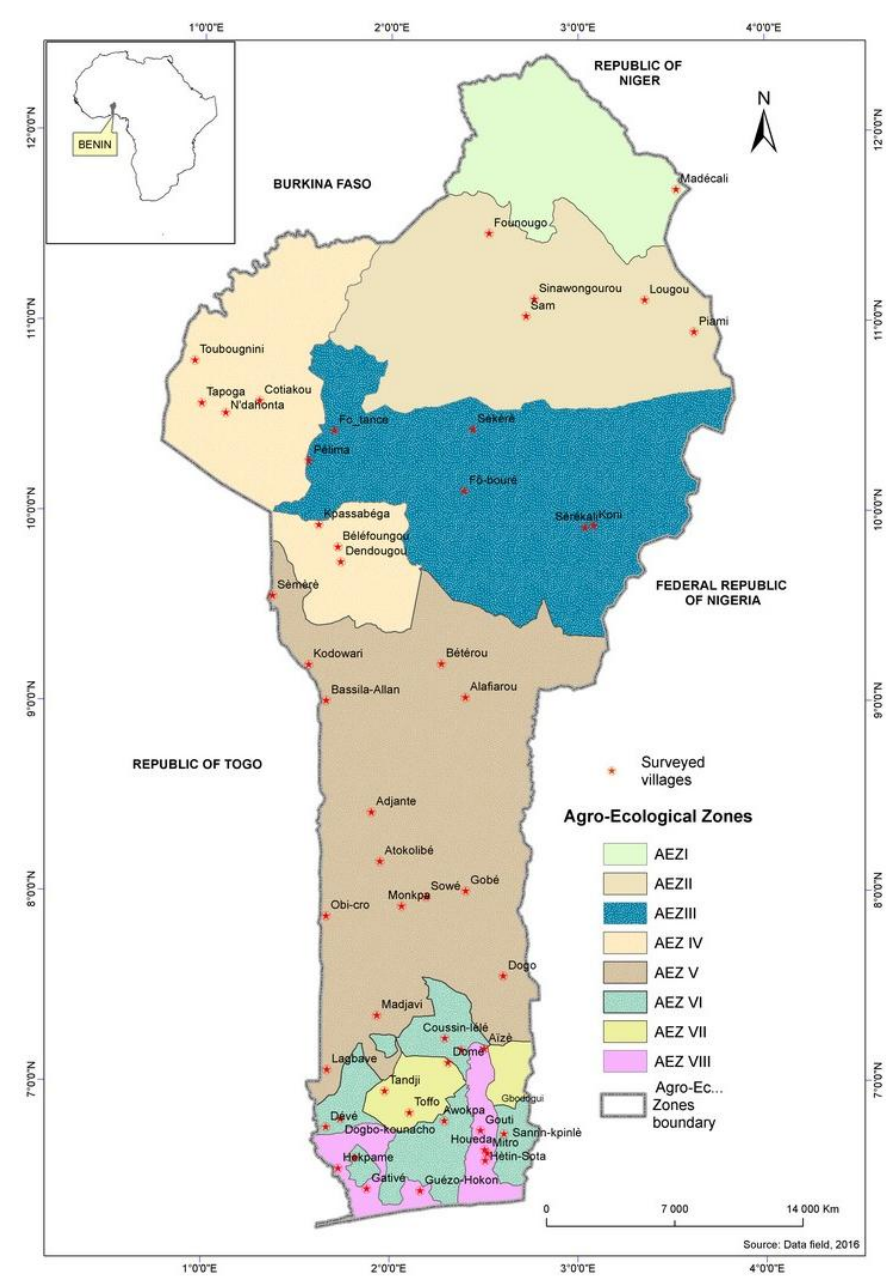

Fig. 1: Benin map showing the agro-ecological zones and the geographic positions of villages surveyed.

\section{Selection of respondents}

The total number of respondents were selected using the normal approximation of binomial distribution method (Dagnelie 1998):

The formulae used was $\mathrm{N}=\left[\left(\mathrm{U}_{1-\alpha / 2}\right)^{2} \times \mathrm{p}(1-\mathrm{p})\right] / \mathrm{d}^{2}$,

Where $U_{1-\alpha / 2}$ is the value of the random normal variable for the value of probability of $1-\alpha / 2, \alpha$ is the risk of error. For $\alpha=5 \%$, the probability $1-\alpha / 2=0.975$ and we have $U_{1-\alpha / 2}=1.96 ; p$ is proportion of people involved in maize production in studied area and $\mathrm{d}$ the range of error estimation at 5\% in this study (Dagnelie, 1998). A total of 1006 farmers were selected for the survey.

\section{Survey and data collection}

A survey was conducted from May to June 2014. With the help of semi-structured questionnaires, both quantitative and qualitative data were collected from the respondents. In each village, focus group discussions were carried out with the help of a local translator. Each focus group was made up of between 20 to 30 maize farmers. Farmer in each group submitted samples of different maize varieties grown in the locality. Based on this, the varieties of maize grown by the farmers were obtained. Also based on a PRA assessment, farmers ranked different production constraints linked to maize production in their village. The identified constraints were ranked based on their severity as described by Orobiyi et al. (2013). Data were also collected on the local name of each variety, the maturity period of each accession, color and shape of maize seed, origin, yield potential, tolerance to drought and resistance to pest and disease as observed by farmers.

Individual survey included 10 to 35 producers taken in different households selected in each village was investigated according to Dansi et al. (2010). Similarly, socio-demographic characteristics such as sex, age, educational level, number of years maize production, farm size, membership or not to farmer association of the farmers were collected. Finally farmer's production practices, sources of seeds, their knowledge of availability of improved varieties, and reasons for choosing and planting a particular variety were also collected.

\section{Data analysis}

Data collected were analyzed using the XLSTAT 2016 software after it has been organized and coded using the spread sheet of Microsoft Excel. Tables and figures were used to display the results of the analyzed data as described by Kisauzi et al. (2012). The production constraints reported were analyzed based on the total number of villages/groups (NTV) in which the constraint was cited, the top 5 principal constraints (PCO) reported among the groups/villages and the number of villages where the constraint is major and is rated first (MAC).

Thus, the importance of a constraint was determined by the formula $\mathrm{IMC}=(\mathrm{NTV}+\mathrm{PCO}+\mathrm{MAC}) / 3$. The relationship between socio-demographic parameters (gender, age, level of education, years of experience in maize production, farm size) and existing varietal diversity was determined using the Pearson correlation coefficient. Using the Ward aggregation method, the 
diversity between accessions were revealed by the Hierarchical Ascending Classification (HAC) while considering maize accessions as individuals and the parameters to be evaluated as variables.

\section{Results}

\section{Names assigned to maize specie and varieties by producers}

It was observed that maize accessions were assigned different names among the communities. Even among the same community different names were assigned to accessions (Table 2). Among the Bariba community, located in AEZ II and AEZ III, the same maize accession was identified with 2 different names (Gbadénou, Gbèrénou) whilst in Fon in the AEZ VIII, it was identified with 2 names (Gbadé, Agbadé). The naming of the accessions were also observed to be influenced by different factors such as its origin ("Awonli gbayé koun" which means "Maize of Nigeria"), maturity period of the accession ("Sègê yoladji" which means "three-month maize") and seed colour or morphology ("Kougan" meaning "coarse grains") (Fig. 2). Whilst communities in AEZ I named their varieties based on number of days to mature and origin of the accession, farmers in all the remaining AEZ used more than 2 factors to name a particular accession (Fig. 2).

Table 2. Different names of maize specie given by different ethnic groups.

\begin{tabular}{lll}
\hline $\mathbf{N}^{\circ}$ & Ethnic group & Species name \\
\hline 1 & Adja & Bafo \\
2 & Aizo & Gbaa, Gbadé \\
3 & Annii & Artchéfounon, Arana \\
4 & Bariba & Gbadénou, Gbèrénou \\
5 & Berba & Baiya \\
6 & Boo & Mancé \\
7 & Dendi & Agbado \\
8 & Fon & Gbadé, Agbadé \\
9 & Foodo & Amonboyo \\
10 & Gnidé/gountéma & Segyoudi, Abadiyo \\
11 & Holli & Gbadé \\
12 & Idaatcha, Ifè & Gbado \\
13 & Mahi & Gbadé, gbado \\
14 & Nago & Agbado \\
15 & Natimba & Sègê \\
16 & Sahouè & Yovokouin \\
17 & Wama & Manan so \\
18 & Watchi & Ebli \\
19 & Wémè & Agbayé,Gbayé, Gbadé \\
20 & Yom & Manzô \\
21 & Tanika & Paaza \\
\hline
\end{tabular}

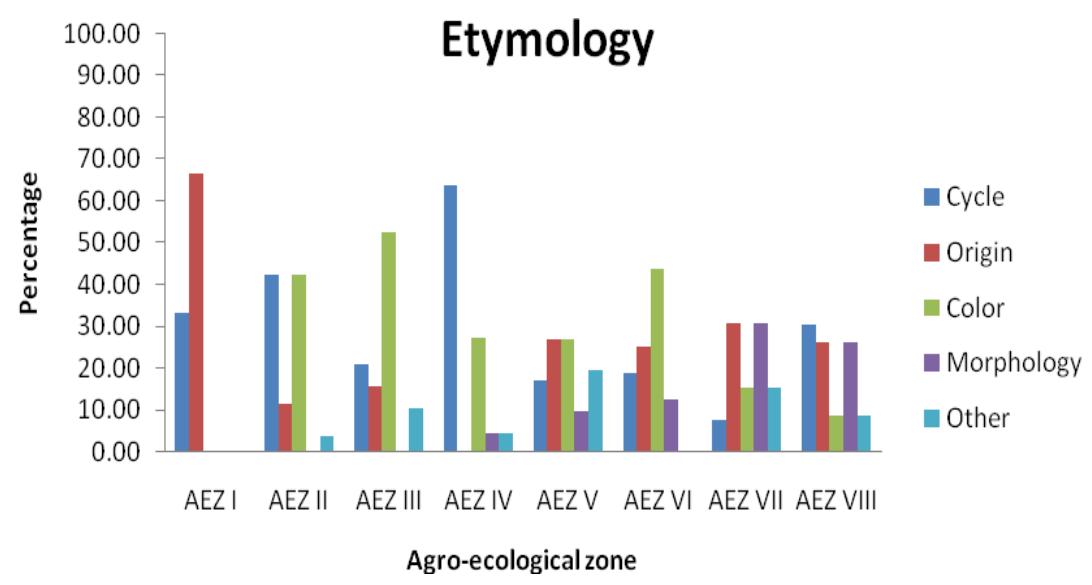

Fig. 2: Etymology of local names of varieties of maize per zone of production. 


\section{Origin and diversity of maize in the various study villages}

Subject to synonymy, a total of 161 maize accessions/ names were recorded from the 51 villages surveyed. It was observed that $93.2 \%$ and $6.8 \%$ were local and exotic (introduce) accessions respectively. With respect to the total maize accessions, $56.8 \%$ were improved varieties and had been received by the producers through various research centers whilst $43.2 \%$ of the materials were not certified as improved varieties (Fig. 3). The results also showed the low adoption of improved varieties among the farmers. Results of the survey across the various AEZs showed that majority of the maize accessions produced by farmers were of local origin and not introduced from different countries (Fig. 3). Similarly, most of the farmers were found to be producing unimproved (traditional) varieties as against improved varieties developed from various research centers
(Fig. 3). The number of farmers using improved varieties ranged between $7.3 \%$ and $17.4 \%$ among farmers in AEZ II, AEZ V, AEZ VII and AEZ VIII (Fig. $3)$. Based on visual/morphological examination such as maize cobs, grains size and shapes diversity were observed in the maize accessions (Fig. 4).

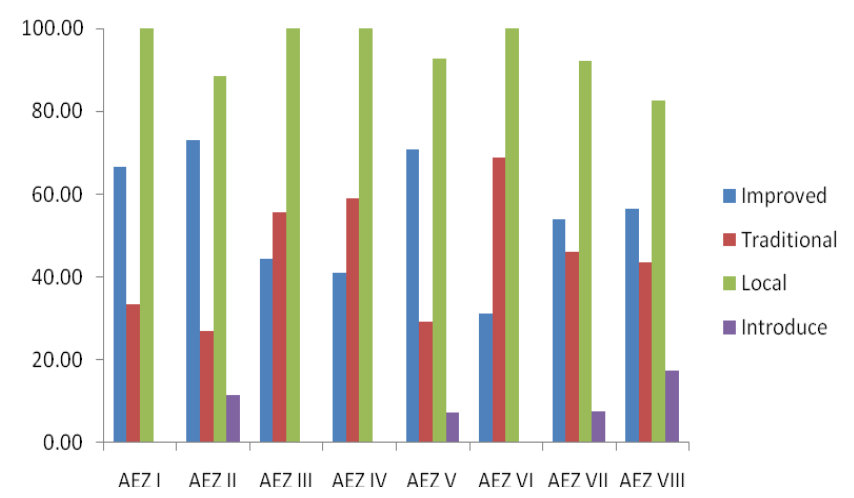

Fig. 3: Origin and status of varieties of maize collected in Benin.

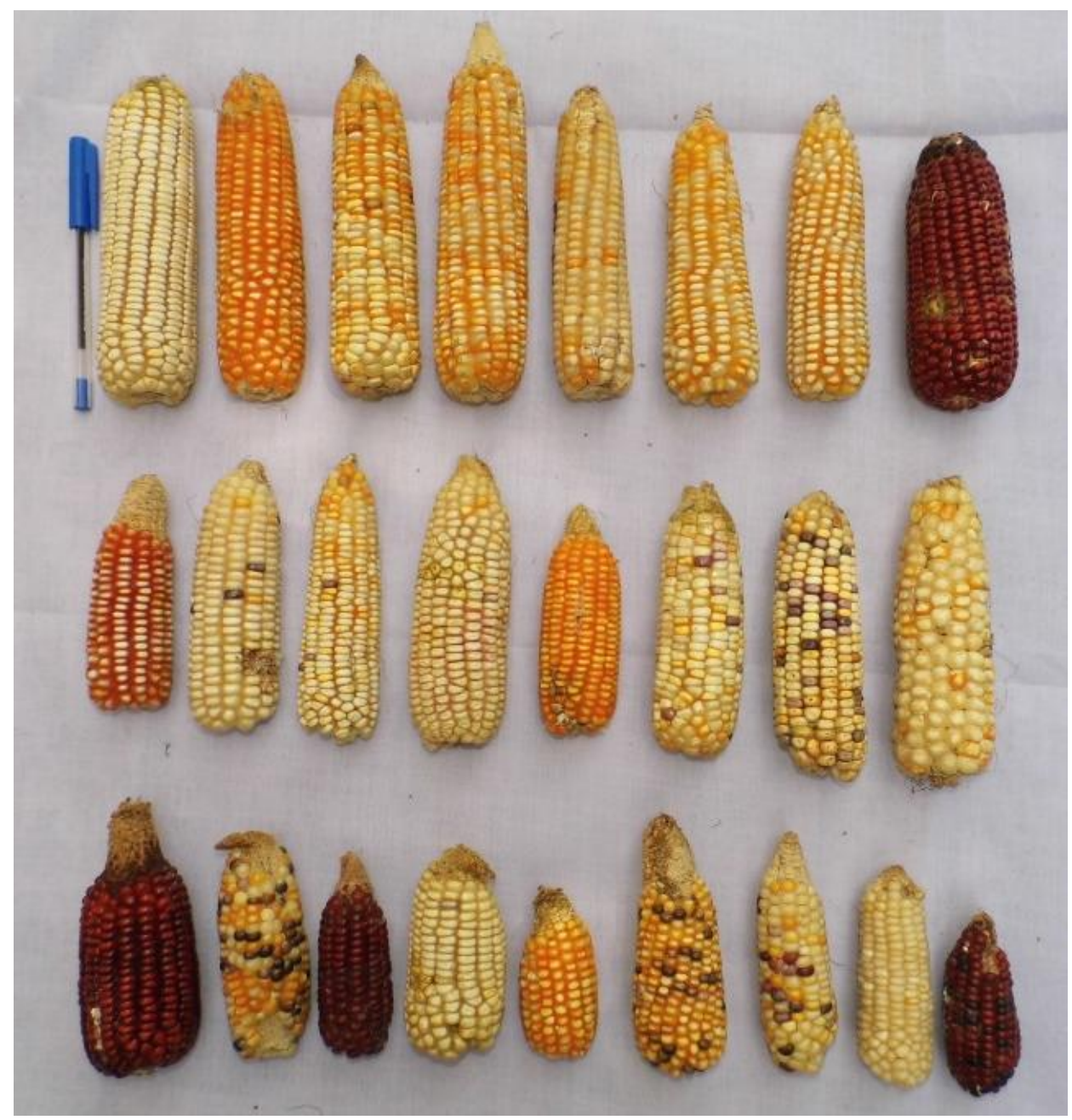

Fig. 4: Diversity between the maize accessions collected in Benin. 


\section{Analysis of diversity by the ascending hierarchical classification}

An ascending hierarchical classification (AHC) was performed on the basis of six characters considered per variety during the collection phase. The dendrogram obtained by the Ward aggregation method (minimization of intra-class variance) separated the accessions into four (4) clusters (Fig. 5). The dominant accession identified in each of the groups resulting from this classification is presented in Table 5. Accessions in Cluster 1, comprised $11.7 \%$ of the total number of accessions analyzed, and consisted of accessions with low grain yield, tolerance to drought, agronomic growth performance on marginal soil and susceptibility to storage pest according to farmers perceptions. Accessions in cluster 2, representing 20.99\% of the total accessions, were characterized with high grain yield, drought tolerance, resistant to storage pest within a year of storage and good agronomic growth performance on marginal soil. In contrast to accessions in cluster 2, accessions in cluster 3 with $61.11 \%$ of total accessions were highly susceptible to storage pest with poor agronomic growth performance on marginal soil. Finally, accessions in cluster 4 representing $6.2 \%$ of total accessions were found to produce the highest grain yield and were highly resistant to storage pest for a period of up to 5 years. Clusters 2 and 4 accessions can therefore be used as a gene donor for the improvement the other clusters accession, to allow them have high resistance to storage insects, good grain yield and good agronomic performance on marginal soils. The distance between the bary centres of clusters 2 and 3 was found to be the least (1.995) showing that these two clusters are closer while the highest distance (5.431) was obtained between clusters 1 and 4 (Table 4).

The variances between the different characteristic of each accession was found to be low. The variances ranged between 1.881 and 2.418 for cluster 4 and cluster 1 respectively (Table 3 ). The $\lambda$ Wilk test performed revealed good yield, reaction to storage pest and good agronomic performance on marginal soil (zero and good) as the main characteristics distinguishing between the accessions (Table 6). There was a highly significant difference between the clusters $(p<0.0001)$ based on these variables. In general, the number of identified accessions per trait according to farmer varied between 1 for a varieties' mean maturity period (4 and 6 months) to 147 for resistance to lodging (Fig. 6). Also, all accessions identified, clustered into four main groups based on the cluster analysis and 91 accessions units were identified (Table 7). It was also observed that each unit had a specific characteristic which separated it from other units in the same group. The number of unit per group was $15,22,47$, and 7 for cluster $1,2,3$ and 4 respectively. The number of accessions per unit also varied from one to nine (Tables $7 \mathrm{a}, 7 \mathrm{~b}, 7 \mathrm{c}$ and $7 \mathrm{~d}$ ).

Table 3. Repartition of accessions into four groups and distances related to their bary center.

\begin{tabular}{llllll}
\hline Group & Number & $\begin{array}{l}\text { Intra-group } \\
\text { variance }\end{array}$ & $\begin{array}{l}\text { Minimal distance to } \\
\text { bary center }\end{array}$ & $\begin{array}{l}\text { Mean distance to } \\
\text { bary center }\end{array}$ & $\begin{array}{l}\text { Maximal distance to } \\
\text { bary center }\end{array}$ \\
\hline G1 & 19 & 2.418 & 0.537 & 1.387 & 2.786 \\
G2 & 34 & 1.965 & 0.746 & 1.330 & 2.874 \\
G3 & 99 & 2.291 & 0.705 & 1.377 & 3.728 \\
G4 & 10 & 1.881 & 0.695 & 1.238 & 2.164 \\
\hline
\end{tabular}

Table 4. Distance to bary center of groups.

\begin{tabular}{llllll}
\hline Groups & G1 & G2 & G3 & G4 \\
\hline G1 & 0 & & & \\
G2 & 3.265 & 0 & 0 & \\
G3 & 2.192 & 1.995 & 4.576 & 0 \\
G4 & 5.431 & 4.587 & & \\
\hline
\end{tabular}

Table 5. Dominant accession of four groups obtained from the AHC.

\begin{tabular}{lllllll}
\hline Group (Accessions) & Cyc & Prod & DT & RV & RSI & PPS \\
\hline 1 (Mandésourouita) & 3 & 0 & 0 & 1 & 0 & 1 \\
2 (Manzo tchroitama) & 3 & 2 & 1 & 1 & 1 \\
3 (Arana wétchéfounon) & 3 & 2 & 1 & 1 & 0 & 1 \\
4 (Agbayésouaton ton) & 3 & 2 & 0 & 1 & 5 \\
\hline
\end{tabular}

NB: Cyc: cycle in month, $3=3$ months; Prod: productivity, $0=$ low, $2=$ good; DT: drought tolerance, $0=$ sensitive, $1=$ tolerant; RV: Resistance to verse, $1=$ resistant; RIS: resistance to storage insects, $0=$ sensitive, $1=$ resistant for 1 year, $5=$ resistant for 5 years; PPS: performance on poor soil, $1=$ low, $3=$ good 
Table 6. One-dimensional test of Wilks.

\begin{tabular}{llllll}
\hline Variable & Lambda & F & DF1 & DF2 & $p$-value \\
\hline Prod & 0.755 & 17.127 & 3 & 158 & $<0.0001$ \\
Res Ins sto & 0.832 & 10.653 & 3 & 158 & $<0.0001$ \\
Perf on poor soil & 0.369 & 90.245 & 3 & 158 & $<0.0001$ \\
\hline
\end{tabular}

\section{DF- Degree of freedom}

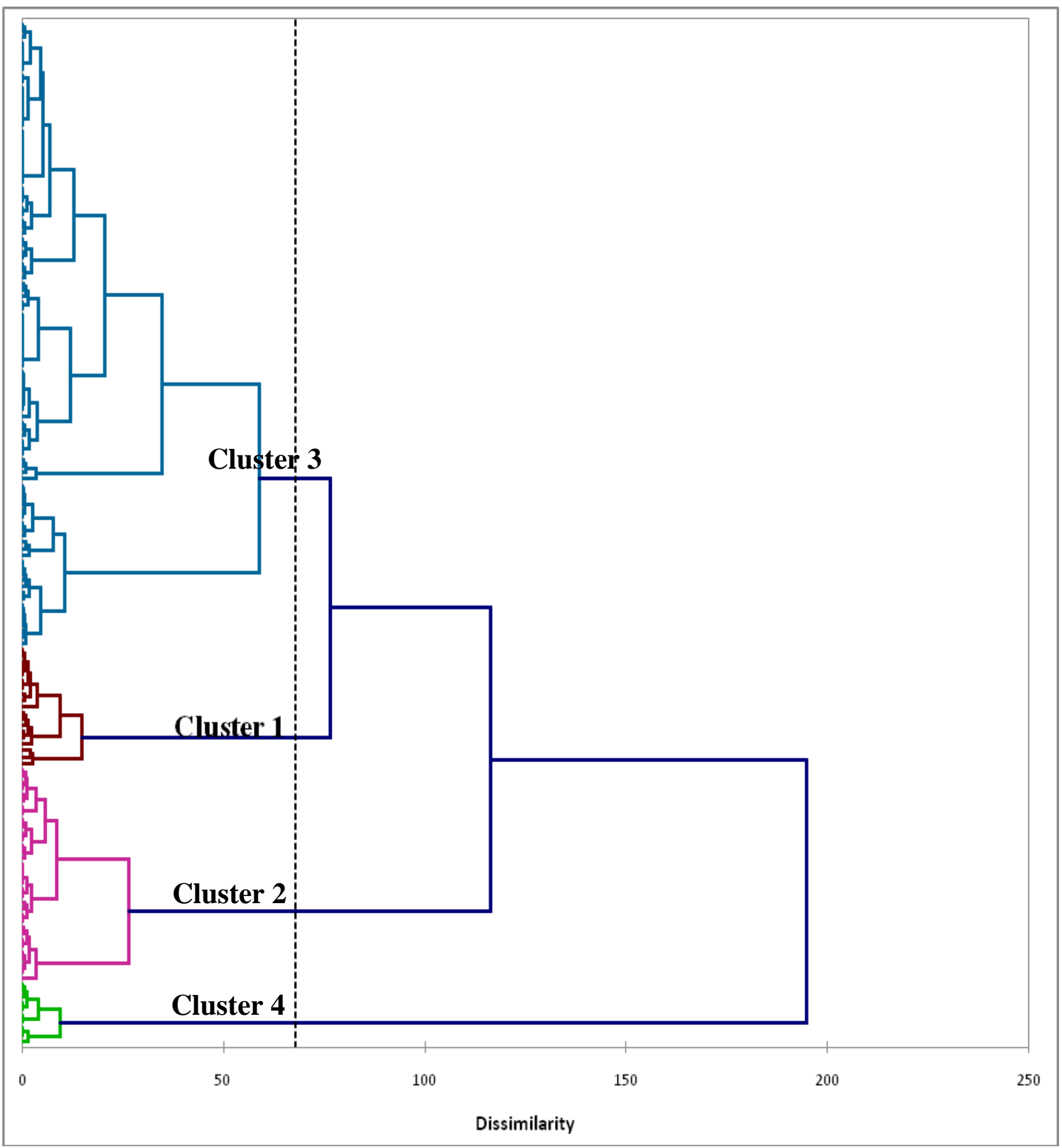

Fig. 5: Hierarchical cluster of 161 accessions collected in Benin following the Ward aggregation method. 




Fig. 6: Number of identified accessions per trait according to farmer's perception. Cyc: mean maturity period of production; Cyc 1: 2 months; Cyc 2: 2.5 months; Cyc 3: 3 months; Cyc 4: 3.5 months; Cyc 5: 4 months; Cyc 6: 5 months; Cyc 7: 6 months; DT: drought tolerance; RV: resistance to verse; RIS: Resistance to insect storage; PPS: performance on poor soil.

Table 7a: Number of unit derived from first group of cluster analysis.

\begin{tabular}{lll}
\hline Unit & Num of acc. & List of accessions and relative productivity \\
\hline U1 & 2 & Gbè kékégou (L); Gouvé (L) \\
U2 & 3 & Gbè chouannou (L); mandé souan (L); QPM (L) \\
U3 & 2 & Mandé sourouita (L); Gbayé-Koungli (L) \\
U4 & 1 & Wlétchivékou (L) \\
U5 & 1 & Mananso tèrè (L) \\
U6 & 1 & Mancé monplana 1 (L) \\
U7 & 1 & Ségê yonika (L) \\
U8 & 1 & Manzo tchroinès (L) \\
U9 & 1 & Agbado carder (L) \\
U10 & 1 & Agbadé carder (L) \\
U11 & 1 & Sourounin (L) \\
U12 & 1 & Mandé sourouinin (L) \\
U13 & 1 & Lingbonoukoun (L) \\
U14 & 1 & Gbogbouin (L) \\
U15 & 1 & Mancé mon aon (L) \\
\hline
\end{tabular}

Num of acc.: number of accessions; L: Low; relative productivity is in bracket.

Table 7b: Number of unit derived from second group of cluster analysis.

\begin{tabular}{lll}
\hline Unit & Num of acc. & List of accessions and relative productivity \\
\hline U1 & 2 & Manzo tchroitama $2(\mathrm{G}) ;$ Agbadé ADF $(\mathrm{G})$ \\
$\mathrm{U} 2$ & 2 & Artchéfounon ranan $(\mathrm{G}) ;$ Congo $(\mathrm{G})$ \\
$\mathrm{U} 3$ & 1 & Gbogbouin $(\mathrm{G})$ \\
$\mathrm{U} 4$ & 1 & Tavèkoun $(\mathrm{G})$ \\
$\mathrm{U} 5$ & 1 & Bafokougan $(\mathrm{G})$ \\
U6 & 1 & Enouatin $(\mathrm{G})$ \\
$\mathrm{U} 7$ & 2 & QPM $(\mathrm{H}) ;$ Shishi $(\mathrm{H})$ \\
$\mathrm{U} 8$ & 2 & Segyoudi wingnita $(\mathrm{G}) ; \operatorname{agbado}$ carder $(\mathrm{G})$ \\
\hline
\end{tabular}




\begin{tabular}{lll}
\hline Unit & Num of acc. & List of accessions and relative productivity \\
\hline U9 & 2 & Gbèsouan $(\mathrm{G}) ;$ Taala $(\mathrm{G})$ \\
U10 & 1 & Baiya béenirou $(\mathrm{G})$ \\
U11 & 4 & Manzo tchroitama $(\mathrm{H}) ;$ mancé tian $(\mathrm{H})$; Gbayé souaton $(\mathrm{H})$; Carder bafo $(\mathrm{H})$ \\
U12 & 2 & Gbayé souaton ton $(\mathrm{H}) ;$ Allaba $(\mathrm{H})$ \\
U13 & 1 & Kounado $(\mathrm{H})$ \\
U14 & 1 & Gbadé souwoué adadé $(\mathrm{H})$ \\
U15 & 2 & Carder blidjin $(\mathrm{H}) ;$ Carder blihéé $(\mathrm{H})$ \\
U16 & 1 & Gbadé vôvô $(\mathrm{G})$ \\
U17 & 1 & Mancé monplana 2 $(\mathrm{H})$ \\
U18 & 2 & Tchankpo $(\mathrm{H}) ;$ gbaa-Vèè $(\mathrm{H})$ \\
U19 & 1 & Gbadé souwoué adadé $(\mathrm{G})$ \\
U20 & 1 & Ebrydji $(\mathrm{G})$ \\
U21 & 2 & Mandé souan $(\mathrm{G}) ;$ Gbadé Tchankpo $(\mathrm{G})$ \\
U22 & 1 & Yokouin sahouèton $(\mathrm{M})$ \\
\hline
\end{tabular}

Num of acc.: number of accessions; G: good; H: high; M: medium; relative productivity is in bracket.

Table 7c. Number of unit derived from third group of cluster analysis.

\begin{tabular}{|c|c|c|}
\hline Unit & Num of acc. & List of accessions and relative productivity \\
\hline U1 & 2 & Ohouya (G); Wlétchivékou (G) \\
\hline $\mathrm{U} 2$ & 1 & Kokourôkpètè (M) \\
\hline U3 & 4 & Sèwaga djimamadè $(G)$; Bétérou1 $(G)$; Sourouigou $(G)$; Wlétchivékou $(G)$ \\
\hline U4 & 1 & Pisaback (G) \\
\hline U5 & 2 & Hybride $(\mathrm{G})$; Gbado kpikpa $(\mathrm{G})$ \\
\hline U6 & 7 & $\begin{array}{l}\text { Arana wètchéfounon }(G) \text {; Artchéfounon }(G) \text { ikinka }(G) \text {; Sèwaga djiomatin }(G) \text {; Alafiarou } 1(G) \text {; } \\
\text { Sourouita2 }(G) \text {; Mandé kpika }(G) \text {; Coopérative }(G)\end{array}$ \\
\hline U7 & 9 & $\begin{array}{l}\text { Baiya bépipialéci }(\mathrm{G}) \text {; Abadiyoyê }(\mathrm{G}) \text {; Sègê yoladji } 1(\mathrm{G}) \text {; Gbè kpikounou }(\mathrm{G}) \text {; Gbè souannou } \\
(\mathrm{G}) \text {; Fonkoun }(\mathrm{G}) \text {; Gbado carder }(\mathrm{G}) \text {; Unknown }(\mathrm{G}) \text {; Carder bli }(\mathrm{G})\end{array}$ \\
\hline U8 & 3 & Artchéfounon carder (TZPB) $(\mathrm{G})$; Artchéfounon fonnon $1(\mathrm{H})$; Sourouita1 $(\mathrm{H})$ \\
\hline U9 & 2 & Mandésouan $(\mathrm{H})$; Sourouirou $(\mathrm{H})$ \\
\hline U10 & 2 & Gbadé souaton $(\mathrm{H})$; Djongbô $(\mathrm{H})$ \\
\hline U11 & 1 & Goun-koun (H) \\
\hline U12 & 2 & Baiya Bétouinzi $(\mathrm{G})$; Kotokoli kouaré $(\mathrm{G})$ \\
\hline U13 & 2 & Baiya Bélaaci $(\mathrm{H})$; Sègê yoladji $2(\mathrm{H})$ \\
\hline U14 & 2 & Paaza cri ita $(\mathrm{H})$; Amomboyo okano $(\mathrm{H})$ \\
\hline U15 & 1 & Mananso kpodé (H) \\
\hline U16 & 1 & Agrique $(\mathrm{H})$ \\
\hline U17 & 1 & Artchéfounon fonnon $2(\mathrm{H})$ \\
\hline U18 & 1 & Agbayé sounènin $(\mathrm{H})$ \\
\hline U19 & 2 & Sac faaba $(\mathrm{H})$; Gbado dani $(\mathrm{H})$ \\
\hline & & Artchéfounon eworonam $(\mathrm{G})$; Amomboyo ognilassa $(\mathrm{G})$; Gbadénou bacadou $(\mathrm{G})$; sourounin $(\mathrm{G})$; \\
\hline $\mathrm{U} 20$ & 9 & Gbèkpika $(\mathrm{G})$; mandé nouakoro $(\mathrm{G})$; mandé kpika $(\mathrm{G})$; Agbayé-kounga $(\mathrm{G})$; Agbayé souènè $(\mathrm{G})$ \\
\hline $\mathrm{U} 21$ & 2 & Amonboyo bankam (G); Ibride (G) \\
\hline $\mathrm{U} 22$ & 5 & Paaza moala (G); Gbédé chouannou (G); Gando (G); gbado sassakawa (G); Gbado ognibo (G) \\
\hline $\mathrm{U} 23$ & 1 & Gbadé Agongba (M) \\
\hline $\mathrm{U} 24$ & 2 & Paaza cri inès $(\mathrm{G})$; Sourounèmè $(\mathrm{G})$ \\
\hline $\mathrm{U} 25$ & 1 & Sèwaga manahin $(\mathrm{G})$ \\
\hline $\mathrm{U} 26$ & 3 & Sourouigou $(\mathrm{G})$; macépoua $(\mathrm{G})$; DMR $(\mathrm{G})$ \\
\hline $\mathrm{U} 27$ & 1 & mandé bisouan $(\mathrm{G})$ \\
\hline $\mathrm{U} 28$ & 1 & Amomboyo onlè $(\mathrm{G})$ \\
\hline $\mathrm{U} 29$ & 1 & mandé numbertia $(\mathrm{H})$ \\
\hline $\mathrm{U} 30$ & 1 & Artchéfounon egboumbonnon (H) \\
\hline U31 & 1 & Massahoué (G) \\
\hline U32 & 2 & Gbadé vè1 $(\mathrm{G})$; Gbadé vè2 $(\mathrm{G})$ \\
\hline U33 & 2 & Agor (G); Kpoléhoun (G) \\
\hline U34 & 2 & Ehrini (G); Awouévi (G) \\
\hline $\mathrm{U} 35$ & 1 & Awonli gbayékou (M) \\
\hline
\end{tabular}




\begin{tabular}{lll}
\hline Unit & Num of acc. & List of accessions and relative productivity \\
\hline U36 & 1 & Agbadé gboo $(\mathrm{G})$ \\
U37 & 1 & Djikoun $(\mathrm{G})$ \\
$\mathrm{U} 38$ & 1 & Gbado carder $(\mathrm{G})$ \\
$\mathrm{U} 39$ & 3 & Kotokoli tchèrè $(\mathrm{G}) ;$ Gbadé Agonlikpahoun $(\mathrm{G}) ;$ Bogan $(\mathrm{G})$ \\
$\mathrm{U} 40$ & 1 & Pozarica $(\mathrm{G})$ \\
$\mathrm{U} 41$ & 1 & Akpayibô $(\mathrm{M})$ \\
$\mathrm{U} 42$ & 1 & Gangbakoun $(\mathrm{G})$ \\
$\mathrm{U} 43$ & 1 & Yayi boni $2(\mathrm{G})$ \\
$\mathrm{U} 44$ & 2 & Gouvè $(\mathrm{G}) ;$ Adjakouin $(\mathrm{G})$ \\
$\mathrm{U} 45$ & 2 & Yayi boni $1(\mathrm{G}) ;$ Unknown $3(\mathrm{G})$ \\
$\mathrm{U} 46$ & 2 & Unknown $1(\mathrm{G}) ;$ Ennindjéré $(\mathrm{G})$ \\
$\mathrm{U} 47$ & 1 & Awouébli $(\mathrm{G})$ \\
\hline Num of acc.: number of accessions; G: good; H: high; M: medium; relative productivity is in bracket.
\end{tabular}

Table 7d. Number of unit derived from fourth group of cluster analysis.

\begin{tabular}{lll}
\hline Unit & Num of acc. & List of accessions and relative productivity \\
\hline U1 & 2 & Ikpetchi $(\mathrm{G}) ;$ Otchoukpamè $(\mathrm{G})$ \\
U2 & 1 & Gbado otchoublihoun $(\mathrm{H})$ \\
U3 & 2 & Agbayé souaton ton $(\mathrm{G}) ;$ Otchoukpamèta $(\mathrm{G})$ \\
U4 & 1 & Macé tingnan $(\mathrm{G})$ \\
U5 & 1 & Gbérénou $(\mathrm{G})$ \\
U6 & 2 & Gbadé vôvô $1(\mathrm{H}) ;$ Gbadé vôvô $2(\mathrm{H})$ \\
U7 & 1 & Grégoire $(\mathrm{H})$ \\
\hline
\end{tabular}

Num of acc.: number of accessions; G: good; H: high; relative productivity is in bracket.

\section{Constraints to maize production in the villages surveyed}

The Maize producers prioritized their constraints based on intensity, frequency and importance for which an urgent solution was needed (Table 8a). In majority $(87.5 \%)$ of the agro-ecological zones surveyed, poor soil fertility and the unavailability of agrochemical input were the prominent constrains to production (Table 8b). Similarly, the lack of good quality seeds and destruction of produce by insect pests, were also identified as major threat to maize production in the study area.

The problem of agricultural input was mainly related to the high cost of fertilizers (NPK and urea) or difficulty in accessing them.

Table 8a. Principal constraints of maize production in Benin.

\begin{tabular}{lllll}
\hline Constraints & TNV & PCO & MAC & \% IMC \\
\hline Soil infertility & 41 & 41 & 34 & $\mathbf{3 1 . 5 2}$ \\
Chemical input lack & 40 & 40 & 4 & $\mathbf{2 2 . 8 3}$ \\
Lack of rain/drought & 25 & 24 & 6 & $\mathbf{1 4 . 9 5}$ \\
Insufficiency of good quality seed & 23 & 22 & 1 & $\mathbf{1 2 . 5 0}$ \\
Insects attack & 10 & 10 & 2 & $\mathbf{5 . 9 8}$ \\
Adventice & 9 & 9 & 0 & 4.08 \\
Flooding & 7 & 7 & 1 & 3.26 \\
Attack of stem borers & 6 & 6 & 0 & \\
\hline
\end{tabular}

Table 8b. Principal constraints of maize production in each agro-ecological zone.

\begin{tabular}{lllllllll}
\hline Constraints & AEZ1 & AEZ2 & AEZ3 & AEZ4 & AEZ5 & AEZ6 & AEZ7 & AEZ8 \\
\hline Soil infertility & 0 & 1 & 1 & 1 & 1 & 1 & 2 & 1 \\
Chemical input lack & 1 & 2 & 2 & 2 & 3 & 2 & 1 & 3 \\
Lack of rain/drought & 0 & 6 & 6 & 4 & 2 & 3 & 4 & 4 \\
Insufficiency of good quality seed & 0 & 3 & 3 & 3 & 4 & 5 & 5 & 5 \\
Insects attack & 0 & 4 & $\mathrm{x}$ & $\mathrm{x}$ & 6 & 4 & 3 & 6 \\
Adventice & 0 & 5 & 4 & 5 & 5 & 6 & $\mathrm{x}$ & $\mathrm{x}$ \\
Flooding & 2 & $\mathrm{x}$ & $\mathrm{x}$ & 6 & $\mathrm{x}$ & $\mathrm{x}$ & 6 & 2 \\
Attack of stem borers & 0 & 7 & 5 & $\mathrm{x}$ & 7 & 7 & $\mathrm{x}$ & $\mathrm{x}$ \\
\hline
\end{tabular}

NB: $x=$ constraint non cited 


\section{Reasons for the selection and use of varieties by farmers}

It was observed that farmers considered several factors in selecting maize varieties to produce (Table 9). Given the constraints listed in the different AEZs, selection factors varied from one AEZ to another. However, the three main factors considered in selecting a particular variety as observed across the 8 AEZs were the potential yield the maturity period and soil conditions. In addition, depending on the production conditions of each zone, factors such as, drought tolerance, and resistance to storage pest were considered in the choice. Thus, given the environmental factors, some producers $(78.65 \%)$ preferred early-maturing accessions because it allowed them to farm twice within a year whilst others chose them because it helped them to avoid the drought period or the shortlived rainy season recorded in some AEZs. However, in AEZs I, II and III, yield and maturity period were the most important criteria considered in selecting a variety (Table 9). Although yield was an important factor in selecting a variety, it was found to be dependent on an accessions tolerance to certain factors such as drought and performance on non-fertile soil. The market demand for a variety was also found to influence the selection and production of a variety (Table 9).

Maize is also subjected to qualitative and quantitative post-harvest losses due to pests attack. Then, according to high destruction of seed after harvest and during conservation a lot of producers included resistance to stocks 'insects attack in their criteria' choice list.

Table 9. Selection criteria of varieties produced by farmers.

\begin{tabular}{|c|c|c|c|c|c|c|c|c|c|}
\hline Criterion of production & AEZ I & AEZ II & AEZ III & AEZ IV & AEZ V & AEZ VI & AEZ VII & AEZ VIII & Mean \\
\hline Yield & 3 & 3 & 3 & 3 & 3 & 3 & 3 & 3 & 3 \\
\hline Performance on poor soil & 0 & 1 & 0 & 1 & 2 & 3 & 3 & 3 & 2.17 \\
\hline Resistance to storage insects & 1 & 1 & 1 & 0 & 1 & 3 & 2 & 3 & 1.71 \\
\hline Demand of market & 2 & 1 & 1 & 0 & 1 & 2 & 2 & 2 & 1.57 \\
\hline Cooking quality & 0 & 1 & 0 & 2 & 1 & 1 & 1 & 1 & 1.17 \\
\hline
\end{tabular}

\section{Sociodemographic characteristics of the maize producers surveyed}

The mean age of the respondents was 43 years \pm 9.083 . The majority $(91.7 \%)$ of producers were men, with $8.3 \%$ of them being women. Based on their ages, the farmers were grouped into four main classes. Thus, $10.44 \%$ of the respondents were below 30 years old (class A); $32.41 \%$ were between 31 and 40 years of age (class B). A percentage of $39.26 \%$ of the respondents were at least 41 years old and up to 50 years old (class C); then $17.89 \%$ of the respondents were at least 51 years old (class D) (Fig. 7). This classification was justified by a discriminant analysis which confirmed that $99.40 \%$ of the grouped individuals were well classified in their group (Fig. 7). Very few of the producers $(20.38 \%)$ were members of any peasant association group. The producers were characterized with a low level of education. It was observed that $71.87 \%$ had no formal education, $20.28 \%$ had completed basic education with only $7.85 \%$ completing receiving secondary education. The number of years spent in maize production by a producer varied between 2 years and 40 years with an average of 12.07 years \pm 6.14 . A variation of 0.125 to 20 ha and 0.2 to 25 ha was respectively obtained for an area planted with maize and a total area planted by producers in each village with a mean of 1.95 ha \pm 1.72 and 4.65 ha \pm 2.98 (Table 10). The analysis of these different mean shows a strong positive correlation between the age of the respondents and the number of years in production and the number of varieties planted (Table 11). There was also a positive correlation between farm size and land availability to the farmer. There was however a low correlation between all the other parameters studied (Table 11).

Table 10. Description of each group of age identified.

\begin{tabular}{lllll}
\hline Group of age & Experience & Cultivated maize area (ha) & Total area (ha) & Number of varieties \\
\hline A & 7 & 1.3 & 3.4 & 1 \\
B & 10 & 1.8 & 4.2 & 1 \\
C & 13 & 1.9 & 4.8 & 2 \\
D & 18 & 2.6 & 5.8 & 2 \\
\hline
\end{tabular}




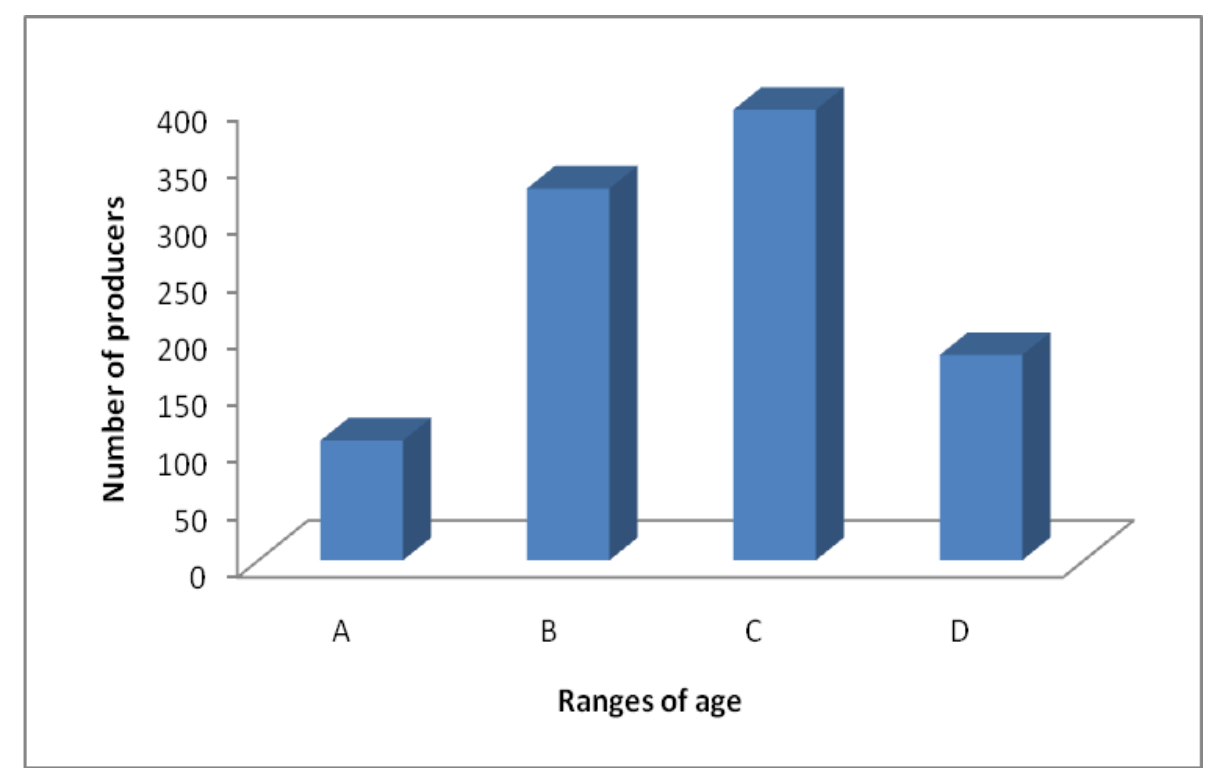

Fig. 7: Total number of producer per group.

Table 11. Correlation between socio-demographic parameter.

\begin{tabular}{llllll}
\hline Variables & Age (year) & Experience & Cultivated maize area (ha) & Total cultivated area & Number of variety \\
\hline Age (year) & 1 & & & & \\
Experience & $\mathbf{0 . 5 8 7}$ & 1 & & & \\
Cultivated maize area(ha) & 0.212 & 0.196 & 1 & 1 & \\
Total cultivated area & 0.256 & 0.202 & $\mathbf{0 . 7 7 1}$ & 0.234 & 1 \\
Number of variety & $\mathbf{0 . 4 1 6}$ & 0.268 & 0.286 & \\
\hline
\end{tabular}

\section{Agronomic Practices}

Maize is the most consumed cereal in Benin. A percentage of $64.51 \%$ of farmers noted a growth of its production. The study revealed that majority $(90.85 \%)$ of maize farmers' had adopted various techniques for preserving their seed. Of these, $79.87 \%$ of them selected good looking seeds and stored in bags either with or without winnowing plus treatment with chemicals such as sofagrain, temephos, and DD force to avoid destruction by storage pests. Some $(11.93 \%)$ stored in earthen drums filled with corn kernels and ash or chili pepper whilst others stored by tying corn spathes to the ceiling of kitchens. Only $31.71 \%$ of respondents soaked seeds in water as pre-emergence treatment to accelerate germination. Planting was done on ridges mainly due to issues such as poor soil fertility $(32.81 \%)$, ease of tillage $(39.65 \%)$ and increase in yield potential $(18.75 \%)$. The number of seeds per hill varied among farmers in various localities and ranged from 1 to 4 seeds/hill.

Most (35.88\%) of the farmers practiced mixed cropping. Maize was intercropped with crops such as cassava, sorghum, soybean, millet, cowpea, earth pea, groundnut, sesame or even yam.
It was also observed that $54.87 \%$ of the farmers applied fertilizer (NPK and Urea) on their field with varied application time. More than half $(56.16 \%)$ of the farmers applied the fertilizer 15 days after planting (DAP) while remain applied it $30 \mathrm{DAP}$. The application rate was also found to differ among the farmers as $67.39 \%$ applied $150 \mathrm{~kg} / \mathrm{ha},(100 \mathrm{~kg} / \mathrm{ha}$ of NPK and $50 \mathrm{~kg} / \mathrm{ha}$ of urea) while $32.61 \%$ applied $200 \mathrm{~kg} / \mathrm{ha},(150 \mathrm{~kg} / \mathrm{ha} . \mathrm{Kg} / \mathrm{ha}$ of NPK and $50 \mathrm{~kg} / \mathrm{ha}$ of urea). Depending on the rainfall pattern maize planting was carried out from June to August in the northern departments of AEZ I, II, and III, which are characterized by a single rainy season. In the central and southern part of the country where two major planting seasons are possible, planting was done between May - July, and February - April. The early maturing maize varieties were produced in the south in the month of March to avoid the drought season experienced.

\section{Discussion}

Maize adapts to a wide range of edapho-climatic conditions. It is produced in all the agro-ecological zones of Benin Republic and most especially likes soils with a light structure, deep and easy to cultivate 
(Adégbola and Aloukoutou, 2011). The identification of maize varieties by seed color, seed size or maturity period as observed in the current study corroborates the work of several authors in Mexico (Soleri and Cleveland, 2001; Brush and Perales, 2007) and Togo (Adoukonou-Sagbadja et al., 2006) were farmers used similar traits to distinguish between varieties. The results of the current study also confirms the finding of others authors (Sawadogo and Balma, 2003; Jiro et al., 2011) that agro-morphological characters are easily used to distinguish between varieties among rural farmers. The low adoption rate clearly shows the slow adoption rate by farmers which could be due to the high rate of farmers with no formal education and involvement of many aged farmers, although the older farmers possess many years of experience and hold on a great diversity of maize accession. The poor adoption could also be attributed to the limited information and extensions services available to farmers or lack of access to these improved varieties. The socio-cultural value associated with some local accessions may have contributed to the continual production of these materials compared to the improved materials.

The constraints listed by farmers during this study are similar to constraints reported in several countries such as Kenya (Odendo et al., 2001) and Ivory Coast (N'da et al., 2013). The poor fertility of soil across the various AEZ according to Pingali and Pandey, (2001), is due to the intensive use of lands and the rapid decrease of fallow'. To compensate for the loss of fertility, the right application of fertilizer at the right time and rate is encouraged. It was however observed that NPK and urea application rate was low and poorly timed. The addition of legumes in the cropping system was therefore justified as these legumes are reported to improve soil conditions and nutrient status by fixing nitrogen. The availability and use of good quality seeds is an important in input for agricultural development (Aly and Padonou, 2007; Achigan-Dako et al., 2014). The high use of unimproved seeds as revealed in the study could have contributed to the poor yield recorded by the farmers. According to Achigan-Dako et al. (2014), seeds contribute about $40 \%$ in yield potential of several crops. In all the AEZs of Benin, seed quality and quantity were reduced by post-harvest storage pest. The lack of standardized system of storing seeds contributed significantly to post harvest loss and according to Arouna (2011) storage pests contributes to the massive destruction of seeds hence reduces the availability of planting materials, encourages use of unimproved seeds. This is due to high cost of improved materials and thereby increasing cost of production and reducing farm incomes (Arouna et al., 2011) which also affects food security (Affognon et al., 2000). The qualities of seeds were however considered as a factor in selecting maize variety only when it was intended for consumption and not for market. This clearly shows the limited information available to farmers on the importance of seed quality in maize production.

Although 161 maize accessions/names were collected, they clustered into 4 main groups. The groupings of the accessions shows the relatedness of these varieties across the various ethnic groups although each ethnic group had special names assigned to them. Each of the groups had qualities that influenced the naming of the material. Notwithstanding the unique qualities of each group, accessions in Group 2 were found to possess certain desirable traits which can useful in future breeding programs.

\section{Conclusion}

This study identified 161 accessions of maize grown in the 51 selected villages. The names of these varieties were found to be based on mean maturity period, seed color, seed shape of the ear, morphology of the plant, and the origin of the variety. Due to degradation of crop soils and climatic variability, production of this crop is subject to constraints including soil infertility which undermines its potential yield. Farmer's selected maize variety based production constraint encountered in their locality to reduce the impact of the stress. The various traits used by farmers in selecting varieties for their locality/AEZ can serve as a basis for developing improved materials suitable for those areas. Thus, for better conservation and utilization of this existing diversity, it will be important to achieve agromorphologic assessment of these different accessions collected. This assessment combined to their genetic diversity study by the use of molecular markers could help in synonymies clarification and duplicates should be identified. Otherwise, identify the varieties possessing target genes (example of gene related to soil fertility) will be useful in a molecular breeding program.

\section{Conflict of interest statement}

Authors declare that they have no conflict of interest. 


\section{Acknowledgement}

This study was sponsored by the Benin component of the West Africa Agricultural Productivity Program (WAAPP). We gratefully acknowledge the valuable assistance of the technicians of the laboratory of Biotechnology, Genetic Resources and Animal and Plant Breeding (BIORAVE) of the Faculty of Science and Technology of Dassa (Benin).

\section{References}

Achigan-Dako, E.G., Houdegbe, A.C., Glèlè, M., NonoWomdim, R., 2014. Analyse du système de production et de distribution des semences de maïs (Zea mays L.) au Sud-Bénin. Biotechnol. Agron. Soc. Env. 1, 49-60.

Adegbola, P.Y., Aloukoutou, A., 2011. Analyse de la compétitivité du maïs local au Bénin. Programme Renf. Rech. Sur Sécurité Aliment. En Afr. L'Ouest PRESAO Compos. SRAI Rapp. $\mathrm{N}^{\circ} 1$.

Adomou, A.C., 2005. Vegetation Patterns and Environmental Gradients in Benin: Implications for Biogeography and Conservation [Ph. D. thesis] Wageningen. Neth. Univ., Wageningen.

Adoukonou-Sagbadja, H., Dansi, A., Vodouhè, R., Akpagana, K., 2006. Indigenous knowledge and traditional conservation of fonio millet (Digitaria exilis, Digitaria iburua) in Togo. Biodivers. Conserv. 15, 2379-2395.

Affognon, H., Kossou, D., Bell, A., 2000. Développement participatif de technologies postrécolte au Bénin. GTZ Eschborn.

Akoègninou, A., van der Burg, W.J., van der Maesen, L.J.G., 2006. Flore analytique du Bénin.Backhuys Publishers, Wageningen.

Aly, D.J., Padonou, E., 2007. Influence du mode d'égrenage sur la qualité des semences certifiées de maïs dans le Département de l'Atlantique (sudBénin). In: Demand Driven Technologies for Sustainable Maize Production in West and Central Africa (Eds.: Badu-Apraku, B., Fakorede, M.A.B., Lum., A.F., Menkir, A., Ouedraogo, M.). Proceedings of the Fifth Biennial Regional Maize Workshop, IITA-Cotonou, Bénin, 3-6 May, 2005, WECAMAN/IITA, Ibadan, Nigeria. pp.355-362.

Arouna, A., Adégbola, P.Y., Biaou, G., 2011. Analyse des coûts de stockage et de conservation du maïs au Sud-Bénin. Bull. Rech. Agron. Bénin. 2, 13-23.

Badu-Apraku, B., Fakorede, M.A., Oyekunle, M., 2014. Agronomic traits associated with genetic gains in maize yield during three breeding eras in West Africa. Maydica. 59, 49-57.

Boone, P., Stathacos, C.J.D., Wanzie, R.L., 2008. Évaluation Sous-régionale de la Chaine de Valeurs du Maïs. Rapport Technique ATP n 1 (Bethesda, MD, USA: Abt Associates Inc).

Brush, S.B., Perales, H.R., 2007. A maize landscape: Ethnicity and agro-biodiversity in Chiapas Mexico. Agric. Ecosyst. Environ. 121, 211-221.

CountrySTAT, 2014. Food and agriculture data network. Available at: http://countrystatorg/bénin

Dagnelie, P., 1998. Statistique Théorique et Appliquée: Tome 2, Inférence Statistique à une et à Deux Dimensions. BoekLarcier Paris Brux. 659p.

Dansi, A., Adoukonou-Sagbadja, H., Vodouhe, R., 2010. Diversity, conservation and related wild species of Fonio millet (Digitaria spp.) in the northwest of Benin. Genet. Resour. Crop Evol. 57, 827-839.

FAO, 2016. FAOSTAT. Base de données statistiques en ligne (consultable à l'adresse suivante: http:// faostat.fao.org).

Hell, K., Cardwell, K.F., Setamou, M., Poehling, H.-M., 2000. The influence of storage practices on aflatoxin contamination in maize in four agroecological zones of Benin, West Africa. J. Stored Prod. Res. 36, 365382.

Jiro, H., Sawadogo, M., and Millogo, J., 2011. Caractérisations agromorphologique et anatomique $\mathrm{du}$ gombo du Yatenga et leur lien avec la nomenclature locale des variétés. Sci. Nat. 8, 23-36.

Kisauzi, T., Mangheni, M.N., Sseguya, H., Bashaasha, B., 2012. Gender dimensions of farmers' perceptions and knowledge on climate change in Teso sub-region, eastern Uganda. Afr. Crop Sci. J. 20, 275-286.

Kouakou, C.K., Akanvou, L., Konan, Y.A., Mahyao, A., 2010. Stratégies paysannes de maintien et de gestion de la biodiversité du maïs (Zea mays L.) dans le département de Katiola, Côte d'Ivoire. J. Appl. Biosci. 33, 2100-2109.

Loko, Y.L., Dansi, A., Agre, A.P., Akpa, N., DossouAminon, I., Assogba, P., Dansi, M., Akpagana, K., Sanni, A., 2013. Perceptions paysannes et impacts des changements climatiques sur la production et la diversité variétale de l'igname dans la zone aride du nord-ouest du Bénin. Int. J. Biol. Chem. Sci. 7, 672695.

Manda, J., Alene, A.D., Gardebroek, C., Kassie, M., Tembo, G., 2016. Adoption and impacts of sustainable agricultural practices on maize yields 
and incomes: evidence from Rural Zambia. J. Agric. Econ. 67(1), 130-153.

N'da, H.A., Akanvou, L., Kouakou, C.K., 2013. Gestion locale de la diversité variétale du maïs (Zea mays L.) violet par les Tagouana au Centre-Nord de la Côte d'Ivoire. Int. J. Biol. Chem. Sci. 7, 2058-2068.

N'da, H.A., Akanvou, L., Akanvou, R., and Zoro, A.I.B., 2014. Évaluation de la diversité agromorphologique des accessions de maïs (Zea maysL.) collectées en Côte d'Ivoire. J. Anim. Plant Sci. 20, 3144-3158.

Odendo, M., De Groote, H., Odongo, O.M., 2001. Assessment of farmers' preferences and constraints to maize production in moist midaltitude zone of Western Kenya. In: Fifth International Conference of the African Crop Science Society, Lagos, Nigeria October. p.12.

Orobiyi, A., Dansi, A., Assogba, P., Loko, L.Y., Dansi, M., Vodouhè, R., Akouègninou, A., Sanni, A., 2013. Chili (Capsicum annuum L.) in southern Benin: Production constraints, varietal diversity, preference criteria and participatory evaluation. Int. Res. J. Agric. Sci. Soil Sci. 3, 107-120.

Pingali, P.L., Pandey, S., 2001. World maize needs meeting: technological opportunities and priorities for the public sector. Ed.: EnPingali, P.L. CIMMYT 1999-2000 World Maize Facts and Trends. CIMMYT. Mexico, DF.

Sawadogo, M., Balma, D., 2003. Etude agromorphologique de quelques écotypes locaux de gombo cultivés au Burkina Faso. Sci. Tech. Sér. Sci. Nat. Agron. 27, 111-129.

Shiferaw, B., Prasanna, B., Hellin, J., Bänziger, M., 2011. Crops that feed the world 6. Past successes and future challenges to the role played by maize in global food security - Springer. Food Secur. 3, 307-327.

Soleri, D., Cleveland, D.A., 2001. Farmers' genetic perceptions regarding their crop populations: An example with maize in the Central Valleys of Oaxaca, Mexico. Econ. Bot. 55, 106-128.

XLSTAT, 2016. Logiciel d'analyse de données statistiques pour Microsoft.

\section{How to cite this article:}

Bonou-gbo, Z., Djedatin, G., Dansi, A., Dossou-Aminon, I., Odjo, C. T., Djengue, W., Kombate, K., 2017. Ethnobotanical investigation and collection of the local maize (Zea mays L.) varieties produced in Benin. Int. J. Curr. Res. Biosci. Plant Biol. 4(5), 9-29. doi: https://doi.org/10.20546/ijcrbp.2017.405.002 


\begin{tabular}{|c|c|c|c|c|c|c|c|c|c|c|}
\hline $\mathbf{N}^{\circ}$ & Accessions & Etymology & Cyc & Col & Ori & Prod & DT & RV & RIS & PPS \\
\hline 1 & Abadiyoyê & White maize & 3 & White & Carder & Good & No & Yes & No & Low \\
\hline 2 & Agbadé ADF & Maize of ADF & 3 & White & ONG ADF & Good & Yes & Yes & 1 year & Good \\
\hline 3 & Agbadé carder & Maize of carder & 4 & White & Carder & Low & No & Yes & No & Low \\
\hline 4 & Agbadé gboo & Maize producing a lot & 3 & White & Madjavi & Good & Yes & No & 2 years & Middle \\
\hline 5 & Adjakouin & & 2.5 & White & Madjavi & Good & No & Yes & 1 year & Low \\
\hline 6 & Agbado carder & Maize of carder & 5 & White & Carder & Low & No & Yes & No & Null \\
\hline 7 & Agbado carder & Maize of carder & 3 & White & Carder & Good & Yes & Yes & No & Middle \\
\hline 8 & Agbayé souaton ton & Maize of three months & 3 & White & Carder & Good & No & Yes & 5 years & Low \\
\hline 9 & Agbayé souènè & Maize of four months & 4 & White & Carder & Good & No & Yes & No & Low \\
\hline 10 & Agbayé-kounga & Long cobs maize & 4 & White & Carder & Good & No & Yes & No & Low \\
\hline 11 & Agor & Ceremonies & 2 & White & Aïzè & Good & No & Yes & 2 years & Low \\
\hline 12 & Agrique & Project & 4 & White & Carder & Very good & No & No & No & Low \\
\hline 13 & Akpayibô & Black spathe & 3 & White & Lokossa market & Middle & Yes & Yes & 1 year & Low \\
\hline 14 & Alafiarou 1 & Unknown & 3 & White & Carder & Good & Yes & Yes & No & Low \\
\hline 15 & Allaba & Long cobs Maize & 3 & White & Hetin-sota & Very good & Yes & No & No & Good \\
\hline 16 & Amomboyo ognilassa & Maize of four months & 4 & White & Sèmèrè & Good & No & Yes & No & Low \\
\hline 17 & Amomboyo okano & Maize of three months & 3 & White & Carder & Very good & Little & Yes & No & Null \\
\hline 18 & Amomboyo onlè & Maize of six months & 6 & White & Sèmèrè & Good & No & Yes & No & Low \\
\hline 19 & Amonboyo bankam & Small maize & 2.5 & Yellow & Sèmèrè & Good & No & Yes & No & Null \\
\hline 20 & Arana wètchéfounon & Maize of three months & 3 & White & Carder & Good & Yes & Yes & No & Low \\
\hline 21 & Artchéfounon carder (TZPB) & Maize of carder & 3 & Blanche & Carder & Very good & Yes & Yes & No & Low \\
\hline 22 & Artchéfounon egboumbonnon & Big maize & 6 & White & bassila-allan & Very good & Yes & Yes & No & Good \\
\hline 23 & Artchéfounon eworonam & Maize of four months & 4 & White & Carder & Good & No & Yes & No & Low \\
\hline 24 & Artchéfounon fonnon (1) & White maize & 3 & White & Carder & Very good & Yes & Yes & No & Low \\
\hline 25 & Artchéfounon fonnon (2) & White maize & 4 & White & Carder & Very good & Yes & Yes & No & Low \\
\hline 26 & Artchéfounon ikinka & Red Maize & 3 & Yellow & Carder & Good & Yes & Yes & No & Low \\
\hline 27 & Artchéfounon ranan & Red maize & 3 & Yellow & Carder & Good & Yes & Yes & No & Good \\
\hline 28 & Awonli gbayékoun & Maize of Nigeria & 3 & White & Nigéria & Middle & No & Yes & 3 years & Low \\
\hline 29 & Awouébli & From our home & 3 & White & Gativé & Good & No & No & 1 year & Low \\
\hline 30 & Awouévi & From our home & 3 & White & Lokossa market & Bonne & No & Yes & 3 years & Low \\
\hline 31 & Bafo kougan & Gross grain maize & 3.5 & White & Dévé & Good & No & No & 1 year & Good \\
\hline 32 & Baiya béenirou & Maize of four months & 4 & White & Carder & Good & No & Yes & No & Middle \\
\hline 33 & Baiya Bélaaci & Maize of three months & 3 & White & Carder & Very good & Little & Yes & No & Low \\
\hline 34 & Baiya bépipialéci & Maize multicoloured & 3 & Multicoloured & Toubougnini & Good & No & Yes & No & Low \\
\hline 35 & Baiya Bétouinzi & Red maize & 3 & Yellow & Toubougnini & Good & Little & Yes & No & Low \\
\hline 36 & Bétérou1 & - & 2 & White & Carder & Good & Yes & Yes & No & Low \\
\hline 37 & Bogan & Great surface & 3 & White & Lagbavé & Good & Yes & Yes & 1 year & Low \\
\hline 38 & Carder bafo & Maize of carder & 3 & White & Carder & Very good & Yes & Yes & No & Good \\
\hline
\end{tabular}




\begin{tabular}{|c|c|c|c|c|c|c|c|c|c|c|}
\hline $\mathbf{N}^{\circ}$ & Accessions & Etymology & Cyc & Col & Ori & Prod & DT & RV & RIS & PPS \\
\hline 39 & Carder bli & Maize of carder & 3 & White & Carder & Good & No & Yes & No & Low \\
\hline 40 & Carder blidjin & Red Maize of carder & 2 & Yellow & Carder & Very good & Yes & Yes & No & Good \\
\hline 41 & Carder blihéé & White maize of carder & 2 & White & Carder & Very good & Yes & Yes & No & Good \\
\hline 42 & Carder1 & Carder & 3 & White & Carder & Good & No & Yes & No & Low \\
\hline 43 & Carder2 & Carder & 3 & White & Carder & Low & No & Yes & No & Null \\
\hline 44 & Congo & - & 3 & Multicoloured & Sinanwongourou & Good & Yes & Yes & No & Good \\
\hline 45 & Coopérative & Gift of carder & 3 & White & Carder & Good & Yes & Yes & No & Low \\
\hline 46 & Djikoun & Rainy seeds & 3 & White & Aïzè & Good & Little & Yes & 2 years & Middle \\
\hline 47 & Djongbô & Giant & 3 & White & Lokossa market & Very good & No & Yes & No & Low \\
\hline 48 & DMR & DMR & 3 & White & Carder & Good & Yes & Yes & No & Null \\
\hline 49 & Ebrydji & - & 2 & White & Togo & Good & No & Yes & 2 years & Good \\
\hline 50 & Ehrini & Quick maize & 3 & Yellow & Obi-Cro & Good & No & Yes & 3 years & Low \\
\hline 51 & Ennindjéré & Maize of two months & 2 & White & Madécali & Good & No & Yes & 1 year & Low \\
\hline 52 & Enouatin & Eat stem & 4 & Multicolored & Tandji & Good & No & No & 1 year & Good \\
\hline 53 & Fonkoun & Seeds of fon & 3 & White & Aïzè & Good & No & Yes & No & Low \\
\hline 54 & Gando & Peuhl & 4 & White & Bariba & Good & No & Yes & No & Null \\
\hline 55 & Gangbakoun & Multicolored maize & 4 & Multicolored & Awokpa & Good & Yes & Yes & 1 year & Low \\
\hline 56 & Gbaa-Vèè & Red maize & 3 & Yellow & Awokpa & Very good & No & Yes & 2 years & Good \\
\hline 57 & Gbadé Agongba & Maize that overtops a garret & 3 & White & Dogo & Middle & No & No & No & Null \\
\hline 58 & Gbadé Agonlikpahoun & Maize of agonlikpahoun & 3 & White & Dogo & Good & Yes & Yes & 1 year & Low \\
\hline 59 & Gbadé souaton & Maize of three months & 3 & White & Carder & Very good & No & Yes & No & Low \\
\hline 60 & Gbadé souwoué adadé & Maize of two months and half & 2.5 & White & Carder & Very good & No & Yes & No & Good \\
\hline 61 & Gbadé souwoué adadé & Maize of two months and half & 2.5 & Yellow & Guézo-hokon & Good & No & Yes & 2 years & Good \\
\hline 62 & Gbadé Tchankpo & Maize producing a lot & 3 & White & Dogo & Good & No & Yes & 2 years & Good \\
\hline 63 & Gbadé vè 1 & Red maize & 3 & Red & Sanrin-kpinlè & Good & No & Yes & 2 years & Low \\
\hline 64 & Gbadé vè2 & Red maize & 3 & Yellow & Sanrin-kpinlè & Good & No & Yes & 2 years & Low \\
\hline 65 & Gbadé vôvô & Red maize & 3 & Yellow & Dovi-zounou & Good & Yes & Yes & 2 years & Good \\
\hline 66 & Gbadé vôvô 1 & Red maize & 2.5 & Yellow & Coussin-lélé & Very good & Yes & Yes & 5 years & Middle \\
\hline 67 & Gbadé vôvô 2 & Red maize & 3 & Yellow & Coussin-lélé & Low & Yes & Yes & 5 years & Low \\
\hline 68 & Gbadé noubacadou & Maize of four months & 4 & White & Carder & Good & No & Yes & No & Low \\
\hline 69 & Gbado wéwé & Maize white & 3 & White & Carder & Good & Little & Yes & 3 years & Low \\
\hline 70 & Gbadodani & Maize of Dani & 4 & White & Sowé & Very good & No & Yes & No & Null \\
\hline 71 & Gbado kpikpa & Red maize & 3 & Yellow & Carder & Good & Yes & No & No & Low \\
\hline 72 & Gbado ognibo & White maize & 3 & White & Carder & Good & No & Yes & No & Null \\
\hline 73 & Gbado otchoublihoun & Maize of four months & 4 & White & Carder & Very good & No & Yes & 5 years & Low \\
\hline 74 & Gbado sassakawa & Sassakawa project & 3 & White & Carder & Good & No & Yes & No & Null \\
\hline 75 & Gbayé souaton & Maize of three months & 3 & White & Carder & Very good & Yes & Yes & No & Good \\
\hline 76 & Gbayé souaton ton & Maize of three months & 3 & White & Carder & Very good & Yes & No & No & Good \\
\hline 77 & Gbayé-Koungli & Small cobs maize & 2.5 & White & Carder & Low & No & Yes & No & Low \\
\hline
\end{tabular}




\begin{tabular}{|c|c|c|c|c|c|c|c|c|c|c|}
\hline $\mathbf{N}^{\circ}$ & Accessions & Etymology & Cyc & Col & Ori & Prod & DT & $\mathbf{R V}$ & RIS & PPS \\
\hline 78 & Gbè chouannou & Red maize & 3 & Multicoloured & Bariba & Low & No & Yes & No & Null \\
\hline 79 & Gbè kékégou & Multicoloured maize & 2.5 & Multicoloured & Bariba & Low & No & Yes & No & Null \\
\hline 80 & Gbè kpika & White maize & 4 & White & Bariba & Good & No & Yes & No & Low \\
\hline 81 & Gbè kpikounou & White maize & 3 & White & Bariba & Good & No & Yes & No & Low \\
\hline 82 & Gbè souan & Red maize & 3 & Red & Sinanwongourou & Good & No & Yes & No & Middle \\
\hline 83 & Gbè souannou & Red maize & 3 & Yellow & Bariba & Good & No & Yes & No & Low \\
\hline 84 & Gbé déchouannou & Red maize & 3 & Yellow & Fô-tancé & Good & No & Yes & No & Null \\
\hline 85 & Gbérénou & Red maize & 3 & Red & Bariba & Good & Yes & Yes & 5 years & Null \\
\hline 86 & Gbogbouin (1) & Yellow maize & 2 & Multicolored & Lagbavé & Low & No & No & No & Good \\
\hline 87 & Gbogbouin (2) & Yellow & 3 & Yellow & Toviklin & Good & No & Yes & No & Good \\
\hline 88 & Goun-koun & Seeds of Goun & 3 & White & Mitro & Very good & No & Yes & 1 year & Low \\
\hline 89 & Gouvè & Red maize & 2.5 & Yellow & Carder & Good & No & Yes & 1 year & Low \\
\hline 90 & Gouvè & Red seed & 2 & Yellow & Carder & Low & No & Yes & No & Null \\
\hline 91 & Grégoire & Fields are good & 3 & Yellow & Hetin-sota & Very good & Yes & No & 5 years & Good \\
\hline 92 & Hybride & Hybrid & 3 & White & Carder & Good & Yes & No & No & Low \\
\hline 93 & Ibride & Hybrid & 2.5 & White & Carder & Good & No & Yes & No & Null \\
\hline 94 & Ikpetchi & Maize of Ikpetchi & 4 & White & Atokolibé & Good & No & Yes & 5 years & Low \\
\hline 95 & Igbado funfun & White maize & 3 & White & Monkpa & Good & No & Yes & No & Low \\
\hline 96 & Igbado Ochoumedji & Maize of two months & 2 & White & Carder & Good & No & Yes & No & Low \\
\hline 97 & Igbado Ochoumèta & Maize of three months & 3 & White & Carder & Good & No & Yes & 1 year & Low \\
\hline 98 & Kokourôkpètè & Gathering by chicken & 2 & White & Togo & Middle & No & Year & No & Low \\
\hline 99 & Agbado kouaré & White maize & 3 & White & Carder & Good & Little & Yes & No & Low \\
\hline 100 & Agbado tchèrè & Red maize & 3 & Red & Carder & Good & Yes & Yes & 1 year & Low \\
\hline 101 & Kounado & Seeds & 2 & White & Carder & Very good & No & No & No & Good \\
\hline 102 & Kpoléhoun & debt-holder waiting for me & 2 & White & Carder & Good & No & Yes & 2 years & Low \\
\hline 103 & Lingbonoukoun & Eye of she-goat & 2.5 & Black & Coussin-lélé & Low & Yes & Yes & 1 year & Middle \\
\hline 104 & Macépoua & White maize & 3 & White & Carder & Good & Yes & Yes & No & Null \\
\hline 105 & Macétingnan & Red maize & 2.5 & Yellow & Carder & Good & Yes & Yes & 1 year & Null \\
\hline 106 & Manan so kpodé & White maize & 3 & White & Carder & Very good & Yes & Yes & No & Null \\
\hline 107 & Manan so tèrè & Red maize & 2.5 & Red & Tanguiéta & Low & Yes & Yes & No & Null \\
\hline 108 & Mancé mon aon & Maize of four months & 4 & White & Carder & Low & No & Yes & No & Good \\
\hline 109 & Mancé monplana (1) & Maize of three months & 3 & White & Carder & Low & No & Yes & 2 years & Null \\
\hline 110 & Mancé monplana (2) & Maize of three months & 3 & White & Carder & Very good & Yes & Yes & 2 years & Good \\
\hline 111 & Mancé tian & Red maize & 3 & Yellow & Carder & Very good & Yes & Yes & No & Good \\
\hline 112 & Mandé bisouan & Red maize & 6 & Red & Sam & Good & Yes & Yes & No & Low \\
\hline 113 & Mandé kpika & White maize & 4 & White & Carder & Good & No & Yes & No & Low \\
\hline 114 & Mandé numbertia & Maize of six months & 6 & White & Carder & Very good & Yes & Yes & No & Low \\
\hline 115 & Mandé sourouinin & Maize of four months & 4 & White & Founougo & Low & Little & Yes & No & Null \\
\hline 116 & Mandé sourouita & Maize of three months & 3 & White & Carder & Low & No & Yes & No & Low \\
\hline
\end{tabular}




\begin{tabular}{|c|c|c|c|c|c|c|c|c|c|c|}
\hline $\mathbf{N}^{\circ}$ & Accessions & Etymology & Cyc & Col & Ori & Prod & DT & $\mathbf{R V}$ & RIS & PPS \\
\hline 117 & Mandé kpika & White maize & 3 & White & Carder & Good & Yes & Yes & No & Low \\
\hline 118 & Mandé nouakoro & Multicolored maize & 4 & Multicolored & Sam & Good & No & Yes & No & Low \\
\hline 119 & Mandé souan & Red maize & 3 & Red & Sinanwongourou & Good & No & Yes & 2 years & Good \\
\hline 120 & Mandé souan & Red maize & 3 & Red & Sam & Low & No & Yes & No & Null \\
\hline 121 & Mandé souan & Red maize & 2 & Yellow & Congo & Very good & Yes & Yes & No & Low \\
\hline 122 & Manzo tchroinès & Maize of four months & 4 & White & Dendougou & Good & Yes & Yes & No & Null \\
\hline 123 & Manzo tchroitama & Maize of three months & 3 & White & Carder & Very good & Yes & Yes & No & Good \\
\hline 124 & Manzo tchroitama (2) & Maize of three months & 3 & White & Carder & Good & Yes & Yes & 1 year & Good \\
\hline 125 & Massahoué & Save home & 2.5 & Yellow & Houéda & Good & No & Yes & 2 years & Low \\
\hline 126 & Ohouya & Quickly & 2 & White & Dogbo-kounacho & Good & No & Yes & No & Low \\
\hline 127 & Otchoukpamè & Maize of three months & 4 & White & Carder & Good & No & Yes & 5 years & Low \\
\hline 128 & Otchoukpamèta & Maize of three months & 3 & White & Carder & Good & No & Yes & 5 years & Low \\
\hline 129 & Paaza cri inès & Maize of four months & 4 & White & Copargo & Good & Yes & Yes & No & Null \\
\hline 130 & Paaza cri ita & Maize of three months & 3 & White & Copargo & Very good & Little & Yes & No & Null \\
\hline 131 & Paazamoala & Red maize & 3 & Yellow & Copargo & Good & No & Yes & No & Null \\
\hline 132 & Pisaback & Small maize & 2.5 & White & Carder & Good & Yes & Yes & No & Low \\
\hline 133 & Pozarica & Project & 3 & White & Carder & Good & Yes & Yes & 2 years & Low \\
\hline 134 & QPM & QPM & 3 & White & Carder & Very good & Yes & Yes & No & Middle \\
\hline 135 & Sac faaba & Maize that produces a lot & 4 & White & Tapoga & Very good & No & Yes & No & Null \\
\hline 136 & Sègê yoladji (1) & Maize of three months & 3 & Red & Peulh & Good & No & Yes & No & Low \\
\hline 137 & Sègê yoladji (2) & Maize of three months & 3 & White & Carder & Very good & Little & Yes & No & Low \\
\hline 138 & Ségê yonika & Maize of four months & 4 & White & N'dahonta & Low & No & Yes & No & Null \\
\hline 139 & Segyoudi wingnita & Maize of three months & 3 & White & Carder & Good & Yes & Yes & No & Middle \\
\hline 140 & Sèwaga djimamadè & Small red maize & 2 & Red & Pelima & Good & Yes & Yes & No & Low \\
\hline 141 & Sèwaga djiomatin & White maize & 3 & White & Carder & Good & Yes & Yes & No & Low \\
\hline 142 & Sèwaga manahin & Purple maize & 4 & Purple & Pelima & Good & No & Yes & No & Null \\
\hline 143 & Shishi & Tight seeds & 3 & White & Toviklin & Very good & Yes & Yes & No & Middle \\
\hline 144 & Sounènin gbadé & Maize of four months & 4 & White & Aïzè & Very good & No & Yes & No & Low \\
\hline 145 & Sourouigou & Maize of three months & 3 & White & Carder & Good & Yes & Yes & No & Null \\
\hline 146 & Sourouirou & Maize of two months & 2 & White & Carder & Very bad & Yes & Yes & No & Low \\
\hline 147 & Sourouirou (2) & Maize of two months & 2 & White & Carder & Very good & Yes & Yes & No & Null \\
\hline 148 & Sourouita (1) & Maize of three months & 3 & White & Unknown & Very good & Yes & Yes & No & Low \\
\hline 149 & Sourouita (2) & Maize of three months & 3 & White & Unknown & Low & Yes & Yes & No & Low \\
\hline 150 & Sourounèmè & Maize of four months & 4 & White & Carder & Good & Yes & Yes & No & Null \\
\hline 151 & Sourounin & Maize of four months & 4 & White & Bariba & Good & No & Yes & No & Low \\
\hline 152 & Sourounin & Maize of four months & 4 & White & Carder & Low & Yes & Yes & No & Low \\
\hline 153 & Taala & Field Protector & 3 & Red & Toviklin & Good & No & Yes & No & Middle \\
\hline 154 & Tavèkoun & Guinean pepper & 3 & Yellow & Nigéria & Good & No & Yes & 1 year & Good \\
\hline 155 & Tchankpo & Very strong maize & 3 & White & Dogbo-kounacho & Very good & No & Yes & 2 years & Good \\
\hline
\end{tabular}


Int. J. Curr. Res. Biosci. Plant Biol. 4(5), 9-29 (2017)

\begin{tabular}{|c|c|c|c|c|c|c|c|c|c|c|}
\hline $\mathbf{N}^{\circ}$ & Accessions & Etymology & Cyc & Col & Ori & Prod & DT & $\mathbf{R V}$ & RIS & PPS \\
\hline 156 & Wlétchivékou & Seeds of two months & 2 & White & Carder & Low & Yes & Yes & No & Low \\
\hline 157 & Wlétchivékou & Seeds of two months & 2 & White & Carder & Good & No & Yes & No & Low \\
\hline 158 & Wlétchivékou 2 & Seeds of two months & 2 & White & Carder & Good & Yes & Yes & No & Low \\
\hline 159 & Yayi boni (1) & Gift of Yayi Boni & 3 & White & Carder & Good & No & Yes & 1 year & Low \\
\hline 160 & Yayi boni (2) & Gift of Yayi Boni & 4 & White & Carder & Good & No & Yes & 1 year & Low \\
\hline 161 & Yokouin sahouèton & Maize of sahouè & 3 & Multicolored & Sahouè & Middle & No & No & 3 years & Good \\
\hline
\end{tabular}

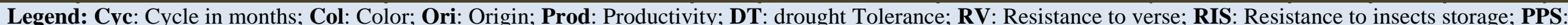
Performance on poor soil. 